\title{
Acting locally, thinking globally? The Relationship between Decentralization in Indonesia and International Human Rights
}

\author{
Luke Lazarus Arnold*
}

International human rights discourse has largely ignored the decentralization of political, fiscal and administrative authority currently taking place across the developing world. By reference to Indonesia's recent transition from a highly centralised system of government to a system of regional autonomy (called Otonomi Daerah, or “Otda"), this article demonstrates the importance of more closely examining the relationship between international human rights and decentralization. In particular, it is argued that an understanding of international human rights can shed light on the dynamics of decentralization and, vice versa, examining decentralization can inform our understandings of international human rights. The essay explains the historical, political and economic context of Otda and briefly describes its current legal framework. It then explores the varied impacts Otda has had on international human rights in Indonesia and how Otda can, in turn, highlight some of the limits and possibilities of international human rights.

\section{Keywords}

Decentralization, International Human Rights, Otda

* B.A./LL.B. (Hons 1, Melbourne), LL.M with Distinction (SOAS), Australian Lawyer and Officer of the Supreme Court of Victoria, Australia. The author is a former Commonwealth Scholar (2007-08) and Consultant to the International Labour Organization in Indonesia (2003-07). The views reflected in this article are, of course, his own. The author may be contacted at: Luke.Arnold@ausaid.gov.au/Address: Unit 69, 47 Kennedy Str. Kingston ACT 2604 Australia 


\section{Introduction}

One of the major criticisms of human rights is that its advocates often use the concept, language and methods behind it in a way that monopolises emancipatory agendas. ${ }^{1}$ One case where this critique cannot be legitimately levelled is the discourse surrounding the recent adoption of a decentralized system of government in Indonesia, known as Otda (from Otonomi Daerah, meaning "Regional Autonomy"). 2 This "nearrevolutionary" 3 shift of power has involved the devolution of significant amounts of fiscal, legislative and administrative authority from the Central Government to legislatures and executive governments in Indonesia's 33 provinces (provinsi) and 465 districts/municipalities (kabupaten/kotamadya). ${ }^{4}$ Otda has, therefore, affected the lives of an incredible number of people: West Java Province, for example, is home to over 39 million - more than the total population of Canada - and one of its districts, Bandung, has a population of over four million - approximately the same as that of Ireland. Mentions of human rights, however, have been conspicuous by their absence from Otda discourse. 5

In fact, since James Madison's 1788 analysis of the "double security" for the "rights of the people" brought about by dividing power between two levels of government, 6 very little attention has been paid to the relationship between human rights and decentralized forms of government.7 This is particularly so in the case of developing countries. Human rights do not rate a mention, for example, among the ten decentralization themes mentioned on the World Bank's Decentralization Homepage. ${ }^{8}$

1 See e.g., David Kennedy, The Dark Sides of Virtue: Reassessing International Humanitarianism (2004).

2 All translations are the author's own, unless otherwise indicated.

3 Jacques Bertrand, Indonesia's Quasi-federalist Approach: Accommodation amid Strong Integrationist Tendencies, 5 INT’L. J. ConST. L. 576, 592 (2007).

4 This is the same level of government. "District" (kabupaten) refers to the 370 rural units of government and "municipality" (kotamadya) refers to the 95 urban units. The average population of these units is 500,000. Provinces (provinsi) are the intermediary level of government between districts/municipalities and the Central Government but, as discussed below, have not been accorded the same degree of power as district/municipal levels of government.

5 Most of the discourse around Otda refers to national stabilization, regional security, good governance and occasionally - democracy. See e.g., Hana A. Satriyo, Decentralization and Women in Indonesia: One Step Back, Two Steps Forward? in Local Power and Politics in Indonesia: Decentralization and Democratization 217, 218 (Edward Aspinall \& Greg Fealy eds., 2003).

6 Madison wrote that: "In the compound republic of America, the power surrendered by the people is first divided between two distinct governments, and then the portion allotted to each subdivided among distinct and separate departments. Hence a double security arises to the rights of the people." THE FEDERALIST No. 51 (James Madison) (emphasis added).

7 See generally Paul Chen, Federalism and Rights: A Neglected Relationship, 40 S. TEx. L. Rev. 845 (1999).

8 The ten themes are "fiscal decentralization, intergovernmental relations, federalism, sub-national financial management, municipal finance, budgeting and taxation, urban policy, voice and participation, democracy, and anti- 
The United Nations, for its part, has made contradictory references to decentralization. In 1999, for example, the term "decentralization" managed to slip inconspicuously into official UN human rights parlance when the Committee on Economic, Social and Cultural Rights stated that national strategies for the right to food require "full compliance with the principles of accountability, transparency, people's participation, decentralization, legislative capacity and the independence of the judiciary." ${ }^{9}$ In 2006 , however, the Commission on Human Rights said, in considering the practice of torture in China, that "at the provincial and municipal levels, the [positive] efforts of the central Government... are significantly hampered by the degree of 'localism' inherent in policing and criminal procedure." 10 Although the United Nations Development Program has, to its credit, attempted to introduce some coherency into its approach to the relationship between human rights and decentralization, 11 these efforts have been very limited.

The limited and contradictory linkages being made between human rights and decentralization are surprising given that decentralization has "emerged as one of the most important trends in development policy," 12 to the point where perhaps only economic liberalization remains a more pervasive policy reform in the developing world.13 In 2005, for example, the African Development Bank held a conference on decentralization where it expressed a "growing recognition" that decentralization is a "critical component" of its agenda.14 Worldwide, approximately 80 percent of

corruption.” World Bank, Decentralization Homepage, available at http://www1.worldbank.org/wbiep/ decentralization (last visited on Feb. 2, 2008).

9 U. N. Comm. on Econ., Soc. \& Cultural Rights, General Comment 12: The Right to Adequate Food (Art. 11), II 23, U.N. Doc. E/C.12/1999/5 (12 May 1999) (emphasis added).

10 U. N. Comm. on Human Rights, Report of the Special Rapporteur on Torture and Other Cruel, Inhuman or Degrading Treatment or Punishment, Manfred Nowak: Mission to China, II 75, U.N. Doc. E/CN.4/2006/6/Add.6 (10 Mar. 2006) (emphasis added).

11 In 2003, the UNDP commissioned a report which emphasised that "participatory decentralization expresses the human rights principle of self-determination and is an end in itself. It is also the means to the realization of political, social, and economic human rights goals...” Leonard Joy, United Nations Development Program, Decentralization and Human Rights: A Systemic Approach 5 (2003).

12 World Bank, Decentralization Homepage, available at http://www1.worldbank.org/wbiep/decentralization/ (last visited on Feb. 2, 2008); See also John F. McCarthy, Contesting Decentralization: Transnational Policy Narratives and the Emergence of Volatile Narratives and the Emergence of Volatile Socio-Legal Configurations in Central Kalimantan, Indonesia, in Mobile People, Mobile Law: Expanding Legal Relations in a Contracting World 153, 153 (Franz von BENDA-BeCKMANN et al. eds., 2005) (discussing decentralization as the sine qua non of public sector reform).

13 Philip Oxhorn, Unravelling the Puzzle of Decentralization, in Decentralization, Democratic Governance and Civil Society in Comparative Perspective: Africa, Asia and Latin America 1, 3 (Philip Oxhorn et al. eds., 2004). Oxhorn also notes that despite its prevalence, decentralization is one of the least noticed political trends worldwide.

14 African Development Bank, Report of the Proceedings: Workshop on Local Governance and Poverty Reduction in Africa, II 1.2, (June 2005). The African countries which attended reflect those whose leadership have expressed the strongest commitment to decentralization: Burkina Faso, Ethiopia, Ghana, Kenya, Madagascar, Malawi, Mali, Namibia, Nigeria, Rwanda, Senegal, South Africa, Tunisia, Uganda, Zambia and Tanzania. 
developing countries are experimenting with some form of decentralization 15 - a percentage which is potentially even higher for countries with populations over five million. 16

This article aims to stimulate discourse on the relationship between human rights and decentralization by examining the relationship between international human rights 17 and Otda. The central argument is two-fold: firstly, that analysing Otda from an international human rights perspective can shed significant light on how Otda is affecting the well-being of people in Indonesia; and secondly, vice versa, that analysing international human rights from an Otda perspective can reveal important limitations and possibilities of the contemporary international human rights movement. The argument proceeds as follows: Part II contextualises Otda by discussing important historical, political and economic considerations surrounding its introduction; Part III outlines the legal framework for the implementation of Otda; Part IV examines several international human rights which have clearly been affected - in positive, negative and mixed ways - by the introduction of Otda; and Part V discusses ways in which Otda highlights some of the challenges facing international human rights. Some concluding remarks are then offered in Part VI.

\section{The Historical, Political and Economic Context of Otda}

\section{A. Decolonisation, Hyper-Centralisation and the F-Word}

Indonesia is the archetypal "imagined community."18 Comprising almost 12,000 inhabited islands which spread across a distance further than from Baghdad to London, the territory of modern Indonesia was not fully united until it was colonised as the Dutch East Indies. ${ }^{19}$ After more than 300 years of colonial rule, the Dutch lost control of Indonesia to the Japanese during World War II and at the end of the war Sukarno declared independence on behalf of Indonesia. The independence war which ensued as the Dutch attempted to regain their colony was marked by Dutch calls for federal governance in the archipelago. 20 When the Dutch eventually agreed to transfer

15 See generally United Nations Development Program, Overview of Decentralization Worldwide (2002).

16 World Bank survey, cited in Arun Agrawal \& Jesse Ribot, Accountability in Decentralization: A Framework with South Asian and West African Cases, 33 J. Developing AREAS 473, 473 (1999).

17 For the purposes of this article, the concept of "international human rights" will be used to describe the set of norms embodied in the International Bill of Human Rights, which comprises the Universal Declaration of Human Rights (UDHR), the International Covenant on Economic, Social and Cultural Rights (ICESCR) and the International Covenant on Civil and Political Rights (ICCPR).

18 See generally Benedict R. O'G. Anderson, Imagined Communities: Reflections on the Origin and SpREAd of NATionalism (1983). Anderson's well-known thesis is said to have been inspired by his time in Indonesia.

19 See e.g., Merle Calvin Ricklefs, A History of Modern Indonesia Since c.1200 (2001).

20 Rizal Sukma, Conflict Management in Post-Authoritarian Indonesia: Federalism, Autonomy and the Dilemma of 
sovereignty to Indonesia in 1949, it was to the federal United States of Indonesia. In a manner analogous to the African National Congress's misgivings about federalism in post-Apartheid South Africa, ${ }^{21}$ great suspicions arose throughout Indonesia about possible Dutch divide-and-rule strategies behind federalism ${ }^{22}$ - suspicions that persist today. 23 In 1950, President Sukarno - setting a precedent later followed in several other newly independent countries 24 - dissolved the colonially bequeathed federal system and established a unitary state with a strong central government. ${ }^{25}$

Sukarno's deep mistrust of federalism and his centralised approach to governance paved the way for the hyper-centralisation of Indonesia that occurred during the reign of his successor, General Suharto. Between 1966 and 1998, Suharto's New Order regime created one of the world's most centralized countries. ${ }^{26}$ All major decisions were made by the Central Government, regional civil servants were appointed by - and often simply sent from - Jakarta27 and Regional Parliaments (Dewan Perwakilan Rakyat Daerah) were simply advisory bodies. 28 The Central Government collected 93 percent of all government revenues and spent 90 percent of this itself. ${ }^{29}$ Regions were not permitted to develop linkages with each other - everything, even plane flights, had to go through Jakarta. 30 As the Centre was the island of Java, this hyper-centralisation meant turning

Democratization, in Autonomy and Disintegration in Indonesia 64, 67 (Damien Kingsbury \& Harky Aveling eds., 2003).

21 As part of a politically negotiated deal with the outgoing Apartheid regime, the ANC reluctantly agreed to create an essentially federalist system. Reservations mainly revolved around its resemblance to Apartheid divide-and-rule Bantustans, local capacity and difficulties in ensuring equitable wealth distribution. As with Otda, the multi-level government system in South Africa is not referred to by the 'f-word'. See e.g., Christina Murray \& Richard Simeon, Promises Unmet: Multi-Level Government in South Africa (forthcoming) (on file with author).

22 Ignasius Ismanto, Decentralization and Democratization in Indonesia's Political Changes, in T A LEgowo AND MunEO Takahashi, eds, Regional Autonomy and Socio - economic Development in Indonesia: A Multidimensional Analyis (2003), at 3; See also Herb Feith, The Decline of Constitutional Democracy in Indonesia (1962).

23 See e.g., Gendur Sudarsono \& Dwi Arjanto, Hari Sabarno: "Kita Bukan Negara Federal" [Hari Sabarno: "We are not a Federal State"], Majalah Tempo (Jakarta), Aug. 27, 2001, available at http://www.tempointeraktif.com (last visited on Feb. 2, 2008); see also John McBeth \& Margot Cohen, Loosening the Bonds, Far EAST. Eco. Rev., Jan. 21, 1999, at 10 (describing regional autonomy as "federalism without the f word").

24 Burma, Libya, Uganda and Cameroon all dissolved federal systems of government shortly after independence.

25 This was perhaps not without foresight, given the collapse of many federations around the developing world in the decades to come: the Mali-Senegal Federation, the Rhodesia-Nyasaland Federation, the West Indies Federation and the federation between Indonesia's neighbours, Malaysia and Singapore.

26 Syarif Hidayat \& Hans Antlöv, Decentralization and Regional Autonomy in Indonesia, in DecentraLization, Democratic Governance and Civil Society in Comparative Perspective: Africa, Asia and Latin America 266, 267 (PHILIP OXHORN et al. eds., 2004).

27 Syarif Hidayat, Too Much Too Soon: Local State Elite's Perspective on, and the Puzzle of, Contemporary Indonesian Regional Autonomy Policy 30 (2007).

28 Peter Holland, Regional Government and Central Authority in INDONeSIA, In INDONESIA: LaW and Society 200, 211 (TiмотнY LiNDSEY ed., 1999).

29 Hidayat \& Antlöv, supra note 26 , at 267.

30 See generally Muriel Charras, The Reshaping of the Indonesian Archipelago After 50 Years of Regional Imbalance, 
the nation into "Greater Java" 31 - both culturally 32 and demographically. ${ }^{33}$ It was taboo to mentioning the "f-word" (ie federalism).

The regions were not always willing partners in the hyper-centralisation project. The use or threat of state violence frequently became Suharto's tools of choice to hold the heterogeneous state together. ${ }^{34}$ As in the Philippines, Kenya, Mexico and Chile, 35 enhanced centralisation was accompanied by increased authoritarianism; the New Order ultimately became a perpetual "state of emergency." 36 Civil society was suppressed and human rights abuses were widespread, particularly in areas where support for the unitary state was weakest. 37

\section{B. After the New Order: Reformasi and Otda}

In the wake of the 1997 Asian economic crisis, and without the same enthusiastic support from his Western backers as he had enjoyed during the Cold War, 38 Suharto was forced to step down. The end of the New Order brought about a wave of democratisation, known as Reformasi. One result of Reformasi was the ratification of the international human rights Covenants 39 and the adoption of a range of human rights

in Regionalism in Post-Suharto Indonesia 92 (MARIBETH ErB et al. eds., 2005).

31 Damien Kingsbury, Diversity in Unity, in Autonomy and Disintegration in Indonesia 99, 111 (Damien Kingsbury \& Harry Aveling eds., 2003); see also Priyambudi Sulistiyanto \& Maribeth Erb, Introduction: Entangled Politics in Post-Suharto Indonesia, in Regionalism in Post-Suharto Indonesia 1, 2 (Maribeth Erb et al. eds., 2005) and Benedict R. O’G. Anderson, Language and Power: Exploring Political Culture in Indonesia (1990).

32 Lindsey notes, for example, that the New Order oversaw a reductionist and paternalistic version of Javanese culture imposed as Indonesian culture throughout the archipelago. Timothy Lindsey, From Rule of Law to Law of the Rulers - to Reformation?, in Indonesia: LaW And Society 11, 15 (Tiмothy LindSEy ed., 1999); see also infra Part IV.A.

33 Over the duration of the New Order, poorer people from Java migrated - often through the state-sponsored Transmigration Programs - to the outer islands, and elites from the outer islands moved to Java. Charras, supra note 30 , at 91 .

34 See e.g., Kingsbury, supra note 31, at 99.

35 See e.g., Decentralization, Democratic Governance and Civll Society in Comparative Perspective: Africa, Asia and LATIN AMERICA (PhiLIP Oxhorn et al. eds.,2004).

36 Sulistiyanto \& Erb, supra note 31, at 1 (citing Gerry van Klinken).

37 Damien Kingsbury \& Harry Aveling eds, Autonomy and Disintegration In Indonesia (2003). As Indonesia's former Director-General for Regional Affairs, Ryaas Rasyid, has stated: "Suharto sent troops to every region considered to be threatening national unity. It created dissatisfaction everywhere." McBeth \& Cohen, supra note 23, at 11.

38 Suharto had come to power through his involvement in suppressing an alleged Communist coup, after which he orchestrated one of the largest, and most-ignored, massacres of the Twentieth Century. See e.g., Ariel Heryanto, Where Communism Never Dies: Violence, Trauma and Narration in the Last Cold War Capitalist Authoritarian State, 2 InT’L. J. CuLt. STUD. 147 (1999).

39 These were incorporated into domestic law through Law No. 11 of 2005 concerning the Ratification of the International Covenant on Economic, Social and Cultural Rights and Law No. 12 of 2005 concerning the Ratification of the International Covenant on Civil and Political Rights.

40 Luke L. Arnold, International Labour Organization, Using Indonesian LaW to Protect and Empower Indonesian DOMESTIC WORKERS (2006). 
legislation. 40 The International Monetary Fund and other international actors used this democratic euphoria and the international community's post-crisis financial leverage to lobby for a more decentralized form of government in Indonesia.41 The main motivating forces behind this were probably a desire to see a smaller role for the state in the economy 42 and to situate government in a space where the newly emerging civil society could "work its magic better".43 It was clear that the perceived inability of the Central Government to achieve these goals was a larger consideration than the perceived ability of the regions. ${ }^{4}$ For Indonesian policymakers, however, the introduction of Otda was less about good governance and much more about "saving the nation" 45 - and the ruling party, Golkar46 - from political upheaval and a potential Balkanisation. 47 The economic crisis had meant that the Central Government could no longer purchase the loyalty of the regions, 48 particularly those who were seeing little returns for their rich natural resources, so devolving authority - and the financial burden for providing public services 49 - was seen as the only option.

It was in this context that the first Otda laws were passed in 1999,50 after very little debate and public consultation. 51 Due to concerns that provinces were large enough to foster separatist struggles, the laws ensured that bulk of the devolved authority leapfrogged the provincial level of government and were instead devolved directly to

41 Hidayat \& Antlöv, supra note26. International actors also played a key role in securing a decentralized form of government in post-Apartheid South Africa. See e.g., Steven Friedman \& Caroline Kihato, South Africa's Double Reform: Decentralization and the Transition from Apartheid, in Decentralization, Democratic Governance and Civil Society in Comparative Perspective: Africa, Asia and Latin America 141, 142 (Philip Oxhorn et al eds., 2004).

42 See e.g., Wicky Meynen \& Martin Doornbos, Decentralizing Natural Resource Management: A Recipe for Sustainability and Equity?, in Democratic Decentralization through a Natural Resource Lens 235, 238 (Jesse C. Ribot and Anne M. LaRson eds., 2005); See also K Muraleedharan, Participatory Development: Issues and Lessons 17 (2006).

43 McCarthy, supra note 12, at 156 (citing Tendler). see also Sukma, supra note20.

44 This is a common theme worldwide. Oxhorn, supra note 13, at 13.

45 Hidayat \& Antlöv, supra note 26 , at 271.

46 With the first democratic elections looming, Suharto's successor, Habibie, hoped (ultimately in vain) to use Otda to create a constituency in the regions. Christopher R. Duncan, Mixed Outcomes: The Impact of Regional Autonomy and Decentralization on Indigenous Ethnic Minorities in Indonesia, 38 Development AND CHANGe 711, 717 (2007).

47 D. Kingsbury, Autonomy and Disintegration IN Indonesia (2002)

48 Hidayat, supra note 27 , at 39.

49 Hidayat \& Antlöv, supra note 26, at 271.

50 Law No. 22 of 1999 concerning Regional Governance and Law No. 25 of 1999 concerning Fiscal Balance between the Central Government and the Regions. These laws were revoked and replaced with new laws in 2004, as discussed in Part III below.

51 T. A. Legowo, Legal Framework and Problems on [Sic] the 1999 Decentralization Program in Indonesia, in Regional Autonomy and Socio-economic Development in Indonesia: A Multidimensional Analysis 20, 41 (T. A. Legowo \& Muneo TAKAHASHI eds., 2003). See also Hidayat \& Antlöv, supra note 26, at 272 (discussing the contrast with the highly participatory processes that preceeded decentralization in South Africa and India). 
the districts and municipalities.52 The laws came into effect in 2001, at which time two million civil servants were transferred to their new regional government employers. 53 Indonesia was transforming from one of the most centralised countries in the world to one of the most decentralized. 54

\section{The 2004 Otda Legal Framework}

The over-reaction to the 1999 laws led to their revocation and replacement with Law No. 32 of 2004 concerning Regional Governance55 and Law No. 33 of 2004 concerning Fiscal Balance between the Central Government and Regional Governments. The major differences between these laws and the 1999 laws is the addition of mechanisms for downward and upward accountability: downward in the sense that Regional Heads (Kepala Daerah) are now directly elected at both provincial and district/municipality levels; 56 upward in the sense that the 2004 Otda laws provide more opportunities for the central government to monitor and intervene in regional affairs. 57 The general breakdown of authority between the Centre and the Regions remains largely the same: the Central Government has exclusive jurisdiction over foreign affairs, defence, internal security (police), the judicial system, monetary policy and religious affairs. 58 Powers to administer and legislate on residual matters, provided this is consistent with national legislation, lie with the regions 59 - provinces for "provincial scale" matters 60 and districts/municipalities for everything else. 61

The Otda legal framework therefore represents a quasi-federal form of

52 This may also have been due to the fact that devolution to provinces would too closely resemble federalism. See, e.g., Ida Aju Pradnja Resosudarmo, Closer to People and Trees: Will Decentralization Work for the People and the Forests of Indonesia?, in Democratic Decentralization through a Natural Resource Lens 110, 114 (Jesse C. Ribot AND ANNE M. LARSON eds., 2005).

53 World Bank, Decentralizing Indonesia: A Regional Public Expenditure Review - Overview Report 1 (2003).

54 Gary F. Bell, Indonesia: the New Regional Autonomy Laws, Two Years Later, SoutheAst Asian Affairs 117, 117 (2003).

55 The title of Law 32/2004 (which is identical to its 1999 predecessor), Regional Governance, differs subtely but significantly from the New Order's attempt at entrenching Central Government control in the regions through Law No. 5 of 1974 concerning Governance in the Regions. Hidayat \& Antlöv, supra note 26, at 273.

56 Law $32 / 2004 \S 24$.

57 Id. $\$ 22$ (listing the "responsibilities" of regional governments), 27 (requiring Regional Heads to tender reports to the Central Government), 30-31 (allowing the President to dismiss Regional Heads if convicted of certain crimes), 175 (allowing the Ministry of Home Affairs to control "budget deficits" in the regions) and 185 (allowing the Ministry of Home Affairs to scrutinize draft regional budgets).

$58 \quad$ Id. $\S 10(3)$.

59 Id. $\S 10(1)$.

60 Id. $\S 13$. This marks a move away from the original scheme where provinces were largely ignored and consigned to playing mainly coordinating roles.

61 Id. $\S 14$. 
decentralization 62 with the regions exercising authority in a wide range of matters, including health, education, village governance, land tenure, trade, labour relations, public order, environmental management and natural resource extraction. ${ }^{63}$ Regional governments can also introduce new taxes.64 Law 33/2004 allocates regional governments the vast majority of revenues from natural resources (except for oil and gas) as well as land and construction tax gathered in their regions. 65 It also creates a mechanism for partially equalising regional disparities through both non-earmarked (DAU) ${ }^{66}$ and earmarked (DAK) ${ }^{67}$ Central Government grants. The Otda laws apply to every region in Indonesia, though Aceh and Papua - regions where separatist movements were most acute - are also covered by "Special Autonomy" (Otonomi Khusus) laws which grant more extensive autonomy. 68

Although the Otda laws are constitutional in nature, they are not constitutionally entrenched.69 The Constitution was in fact amended to reflect the change in power balance, but this goes no further than saying that the regions have a right to autonomy and that this is to be regulated by law "as the prerogative of the Central Government" 70 The Central Government can also annul Regional Regulations (Peraturan Daerah) within 60 days if they conflict with the public interest or national legislation,71 though regions can apply for a judicial review of these decisions in the Supreme Court.72 Individuals or private groups can also apply to have a Regional Regulation judicially reviewed,73 but as discussed in Part IV(D) below, the Supreme Court has adopted a very limited approach to its powers in this regard.

62 See e.g., Bertrand, supra note 3.

63 Law $32 / 2004 \S 14$.

64 Id. $\S 21$.

65 Law 33/2004 $\S 10-26$.

66 Dana Alokasi Umum. Id. $\S \S 27-37$.

67 Dana Alokasi Khusus. Id. $\S \S 38-42$.

68 Law No. 21 of 2001 concerning Special Autonomy for Papua and Law No. 11 of 2006 concerning Acehnese Government. Addition rights include, for example, a greater share of oil and gas revenues, a right to veto certain Central Government laws (Aceh) or implementing regulations (Papua), the right to establish local political parties (Aceh) and jurisdiction over religious affairs (Aceh).

69 Gary F. Bell, The New Indonesian Laws relating to Regional Autonomy: Good Intentions, Confusing Laws, 2 AsiaNPac. L. \& PoL. J. 1, 4-11 (2001).

70 Constitution of the Republic of Indonesia $1945 \S 18$.

71 Law 32/2004 § 145(2). Regional Regulations can be annulled if they conflict with a National Statute (UndangUndang) or an inter-departmental Government Regulation (Peraturan Pemerintah), but it remains uncertain whether a Ministerial Regulation (Peraturan Menteri) can trump a Regional Regulation.

72 Id. $\S 145(5)$. The opposite applies in the case of Aceh, where the presumption is that the Acehnese Regulation (Qanun) is valid and the Central Government must apply to have it judicially reviewed: Law 11/2006 § 235 .

73 Law No. 5 of 2004 concerning the Amendment of Law No. 14 of 1985 concerning the Supreme Court $\S 1$; Law No. 4 of 2004 concerning Judicial Authority $\S 11$. 


\section{Otda through an International Human Rights Lens}

This Part examines the effects of Otda on the realization of several international human rights. A key challenge in doing this is to distinguish between human rights effects attributable to Otda per se and those effects brought about by Reformasi more generally. Whilst any attempt to separate the two will involve some degree of arbitrariness, eight rights can be clearly identified as being directly affected by Otda. These are the rights to: 1) self-determination;74 2) participation in government;75 3) racial equality;76 4)freedom of movement;77 5) freedom of religion;78 6) gender equality;79 7) health;80 and 8) education. 81

On the whole, Otda has enhanced the realisation of rights 1-2, resulted in violations of rights 3-5 and brought about mixed outcomes for rights 6-8. The following three sections present general observations in relation to Otda's impact on each of these sets of rights, with a view to encouraging dialogue and detailed analyses on the issues raised. This is followed by some general comments on how international human rights can inform our understanding of Otda.

\section{A. Otda and the Realisation of International Human Rights}

\section{Self-Determination}

Despite the fact that the term "human rights" (hak asasi manusia) is not mentioned in either of the 2004 Otda laws (or their 1999 predecessors), they have had clear effects on the realisation of the first human right mentioned in the Covenants: self-determination. The meaning of this complex right has been hotly contested 82 and the jurisprudence on it "brief and disappointing" 83 - often simply restating the words of the relevant

74 International Covenant on Economic, Social and Cultural Rights art. 1, Dec. 16, 1966, 993 U.N.T.S. 3) [hereinafter ICESCR]; International Covenant on Civil and Political Rights, art. 1, Dec. 16, 1966, 999 U.N.T.S. 171 [hereinafter ICCPR].

75 Universal Declaration of Human Rights, G.A. Res. 217A, art. 21, U.N. GAOR, 3d Sess., 1st plen. mtg., U.N. Doc. A/810 (Dec. 12, 1948) [hereinafter UDHR]; ICCPR, supra note 74, at art. 25.

76 UDHR, supra note 75, at art. 2; ICCPR, supra note 74, at arts. 2, 20 and 26; ICESCR, supra note 74, at art. 2.

77 UDHR, supra note 75, at art. 13; ICCPR, supra note 74, at art. 12.

78 UDHR, supra note 75, at art. 18; ICCPR, supra note 74, at arts. 2, 18, 20, 26 and 27; ICESCR, supra note 74, at art. 2.

79 UDHR, supra note 75, at art. 2; ICCPR, supra note 74, at arts. 2, 3 and 26; ICESCR, supra note 74, at arts. 2 and 3.

80 UDHR, supra note 75 , at art. 25; ICESCR, supra note 74, at art. 12.

81 UDHR, supra note 75, at art. 26; ICESCR, supra note 74, at arts. 13-14.

82 Its existence as a right, however, has not seriously been called into question since the end of World War II. HENRY J. Steiner \& Philip ALSTon eds., International Human Rights in Context 1255 (2000) (citing Orentlicher).

83 Sarah Joseph et al., The International Covenant on Civil and Political Rights: Cases, Materials, and COMMENTARY 153 (2005). 
articles. ${ }^{84}$ Although some have attempted to apply the "anti-colonial limiting principle" 85 to consign the right to the "history of the struggle for decolonization," 86 and others argue that it is essentially limited to a right of succession,, 8 there are sensible arguments that it is an "ongoing phenomenon" 88 and entails internal self-determination: "a people's pursuit of its political, economic, social and cultural development within the framework of an existing state." 89

Otda has resulted in the enhanced realisation of internal self-determination in two ways. Firstly, most peoples - however defined - now enjoy a greater share of their locally extracted natural resources. 90 They are also better able to pursue their economic development by being permitted to engage in direct export of goods and the processing of natural resources, both of which were routinely denied under the New Order.91 Secondly, Otda has allowed the various peoples of Indonesia to (re-)build institutions that were not permitted to exist during the hyper-centralisation of the New Order.92 From 1979, for example, the structure of every village in the country was remodelled according to the hierarchical structure of Central Javanese villages $(\text { desa })^{93}$ - regardless of the local needs, traditions or population density in the region. Customary laws were essentially supplanted by national policy and many traditional leaders were either coopted into the central bureaucracy or replaced due to not complying with minimum formal education requirements. ${ }^{94}$ By contrast, regions have now begun determine their

84 These provide that the right to self-determination allows all peoples to "freely determine their political status and freely pursue their economic, social and cultural development" (art. 1(1) of both Covenants) and to "freely dispose of their natural wealth and resources" (art. 1(2) of both Covenants). ICCPR, supra note 74; ICESCR, supra note 74, at art. 2.

85 According to which the right to self-determination only entailed the right of colonised peoples to assume sovereignty over the territory, uti possidetis, of their colonisers. Alice Farmer, Towards a Meaningful Rebirth of Economic SelfDetermination: Human Rights Realization in Resource-Rich Countries, 39 N. Y. U. J. INT'L. L. \& PoL. 417, 439 (2006).

86 Philip Alston, ed., Peoples' Rights 259, 271 (2001).

87 See e.g., Gnanapala Welhengama, The Legitimacy of Minorities' Claim for Autonomy through the Right to SelfDetermination, 68 NoRDIC J. INT'L. L. 413 (1999).

88 International Human Rights IN ConTeXt, supra note 82, at 1268.

89 Reference Re Secession of Quebec, [1998] 2 S. C. R. 217, (Can.) at para. 126. A review of the arguments on this point is beyond the scope of this essay. In addition to the Supreme Court of Canada's ruling, "internal selfdetermination" is convincingly argued for in Farmer, supra NOTE 85, and Frederic Kirgis Jr., The Degrees of SelfDetermination in the United Nations Era, 88 AM. J. INT'L L. 304 (1994) (discussing the "many faces" of selfdetermination).

90 See generally Law 33/2004. The assertion of customary law has also led to customary communities earning a greater (though often not yet equitable) share of the forest harvested on their ancestral lands. See e.g., McCarthy, supra note 12 , at 67 .

91 Suharto had ensured that even more simple processing technologies for natural resources, such as those for rubber, rattan and coconut oil, were mainly located on Java. Charras, supra note 30, at 90.

92 Id.

93 Law No. 5 of 1979 concerning Village Governance.

94 See e.g., Holland, supra note 28; Charras, supra note 30; McCarthy, supra note 12. 
own structures of governance, 95 and villages can use Otda laws to, among other things, institute their own dispute resolution mechanisms. ${ }^{96}$ Another possible indication of internal self-determination is the decreasing number of Regional Heads from the highlycentralised and top-down military. 97

\section{Participation in Government}

The advent of "internal pluralism" 98 brought about by the creation of new levels of decision-making has enabled previously marginalised peoples to realise their international human "right to take part in the government." 99 This right is "related to, but distinct from" self-determination, in that it focuses on the actual involvement of citizens in government and their influence in public affairs, rather than simply the form of their government. 100 Otda has assisted the realisation of this right - perhaps inadvertently101 - by creating both downward accountability, as discussed in Part III above, and space for individuals and civil society to influence local decision-makers. Though commentators are divided about the impact of the continued centralisation of political parties on local politics, 102 in several cases local people have exerted an influence over policy in ways that would have been unthinkable prior to Otda. The recent local rejection of a top-down plan to permit the dumping of allegedly toxic waste on the island of Bangka,103 for example, stands in sharp contrast to the New Order's Million-Hectare Peat-Swamp Project, where peatlands in Central Kalimantan were converted to rice paddies despite much protest and few benefits for the local

95 See e.g., West Sumatra Province Regional Regulation No. 9 of 2000 on Guidelines for the Return of Village Governance to the Traditional Nagari System; see also Duncan, supra note 46, at 720.

96 Law 32/2004 § 206. See also Ismanto, supra note 22, at 22.

97 Sukardi Rinakit, Decentralization and the Military, in Regionalism in Post-SuHarto Indonesia 75, 79 (Maribeth ERB et al. eds., 2005).

98 Boaventura de Sousa Santos, State, Law and Community in the World System: An Introduction, 1 Soc. \& LEG. STUD 131, 134 (1992).

99 UDHR, supra note 75, at art. 21. See also ICCPR, supra note 74, at art. 25 , with slightly modified wording as discussed by Steiner. INTERNATIONAL Human Rights In CONTEXT, supra note 82, at 890-99.

100 See generally United Nations Human Rights Committeee, General Comment 25: The Right to Participate in Public Affairs, Voting Rights and the Right of Equal Access to Public Service (Art. 25), III 2, 8, U.N. Doc CCPR/C/21/Rev.1/Add.7 (12 July 1996). Note in particular paras. [2] and [8]. Id.

101 As Oxhorn notes: "Democratization often is not a central concern of policymakers, even democratically elected ones... when addressing the institutions of regional government." Oxhorn, supra note 13, at 10.

102 Compare Michael Buehler, Rise of the Clans, Inside Indonesia (Melbourne), Oct. 2007, available at http://www.insideindonesia.org (last visited on Mar. 1, 2008) with Ati Nurbaiti, Autonomy at Local Party Level Urgent, Expert Says, THE JAKARTA PosT, Aug. 28, 2002, available at http://www.thejakartapost.com (last visited on Mar. 1, 2008).

103 Minako Sakai, The Formation of the Province of Bangka-Belitung, in Autonomy AND Disintegration In INDONESIA 189, 193 (DAMIEN Kingsbury \& HarRy Aveling eds., 2003). 
population.104 Surveys reveal that both men and women now feel they have a greater chance of influencing policy at a local level,105 evidence that is supported by both the growth of local civil society - including village councils, farmer federations and human rights organisations 106 - and the fact that local government officials are now attending many activities run by non-governmental organisations. 107 Some regional governments have even transferred part of their authority to villages, 108 which are now also downwardly accountable.109

\section{B. Otda and the Violation of International Human Rights}

\section{Racial Equality}

While Otda has provided many opportunities to minority groups at a national level who now make up the majority in their region, it has given rise to forms of "ethnic chauvinism" 110 which work against those groups which remain ethnic minorities at a regional level.111 This initially resulted in several instances of inter-ethnic violence across the country as various groups jostled for newly-created local power. 112 It is now manifesting itself in ethnic discrimination, particularly against ethnic groups who have migrated (often several generations earlier) from other parts of the archipelago. The most common examples of this involve (unofficial) preferential access to public service jobs for "sons of the region" (putra daerah), as have been documented in Central Kalimantan Province113 and North Halmahera District.114 In Papua Province, a half-

104 Duncan, supra note46, at 719.

105 See e.g., results of an Asia Foundation survey, cited in Satriyo, supra note 5, at 226.

106 Such organizations are addressing a wide range of issues, ranging from sectarian tension to traffic congestion. See generally Hans Antlöv, Not Enough Politics! Power, Participation and the New Democratic Polity in Indonesia, in Local Power and Politics in Indonesia: Decentralization and Democratization 72 (Edward Aspinall \& Greg Fealy eds., 2003).

107 Hidayat \& Antlöv, supra note 26, at 282. An exception appears to be emerging in relation to the formulation of quasi-religious Regional Regulations, as discussed in Part IV(C) below. See e.g., Satriyo, supra note 5, at 222.

108 See e.g., Jason M. Patlis, New Legal Initiatives for Natural Resource Management in a Changing Indonesia: the Promise, the Fear and the Unknown, in The Politics and Economics of Indonesia's Natural Resources 231,233 (BUDY P. RESOSUDARMO ed., 2005) (discussing the transferral of authority to manage marine parks from the Minahasa District Government in North Sulawesi to local villages).

109 Law 32/2004 arts. 202-216, which provide for the direct election of Village Heads and the ongoing check on Village Head power by a Village Consultative Board.

110 Jamie S. Davidson, Decentralization and Regional Violence in the Post-Suharto State, in REGIONALISM IN PostSuHARTo Indonesia 170, 173 (MARIBETH ERB et al. eds., 2005).

111 See generally Duncan, supra note 46.

112 See generally Gerry van Klinken, Royal Netherlands Academy of Arts and Sciences, Indonesia's New Local Elites (2002), available at http://www.knaw.nl/indonesia/ (last visited on Feb. 8, 2008). See also Sukma, supra note 20.

113 McCarthy, supra note 12 , at 161.

114 Duncan, supra note 46 , at 726. 
Papuan was recently barred from running as Deputy Governor on the basis that he was not fully indigenous. 115 Other forms of racial discrimination are also emerging, such as the denial of timber harvesting rights to non-indigenous ethnic groups in Central Kalimantan 116 and the introduction of new taxes in Bali which "tax non-Balinese Indonesians simply for being non-indigenous." 117 These discriminatory practices are clearly in breach of the International Human Right to the enjoyment of basic rights and freedoms without distinction as to race. 118

\section{Freedom of Movement}

Otda has also led to the widespread violation of the "right to freedom of movement and residence within the borders of each state." 119 Some of these violations have been inspired by the rise of "ethnocracy" described above.120 For example, Otda has been cited as a major factor contributing to attempts by Dayak tribes and ethnic Malays to drive Madurese migrants from the provinces of Kalimantan (Indonesian Borneo), 121 where they were sent as part of the New Order's Transmigration Programme.122 Similarly, local literature in Bali has urged village authorities to evict non-Balinese migrants who do not have a Balinese sponsor.123 Other violations of the right to freedom of movement within Indonesia appear to be driven mainly by economic considerations. The Jakarta Provincial Government, for example, passed a Regional Regulation in 2004 to "stem the flow" 124 of "migrants" from rural areas to the capital.125 A similar policy has reportedly been applied in the Batam Municipality, a wealthy industrial hub, to ensure that temporary internal migrants do not settle there

115 The Special Autonomy law for Papua permits this at a provincial level, but indications are that this policy will also be applied to candidates at district level. Only Native Papuans Allowed to Run for Regional Polls in Indonesian Province, Tempo Magazine (JaKaRTA), Aug. 15, 2006, available at http://infoweb.newsbank.com/ (last visited on Dec. 3, 2007).

116 McCarthy, supra note 12, at 165.

117 Frederick Rawski \& John MacDougall, Regional Autonomy and Indigenous Exclusivism in Bali, 11 INT'L. J. MinoRITY \& GROUP RIGHTS 143, 153 (2004).

118 UDHR, supra note 75, at art. 2; ICCPR, supra note 74, at arts. 2, 20 and 26; ICESCR, supra note 74, at art. 2.

119 UDHR, supra note 75, at art. 13(1). See also ICCPR, supra note 74, at art. 12.

120 A similar situation appears to be emerging in Kenya. See e.g., Gilbert M. Khadiagala \& WInnie V. Mitullah, Kenya's Decentralization through the Devolution of Power: Advances and Limits, in Decentralization, Democratic Governance and Civil Society in Comparative Perspective: Africa, Asia and Latin America 201 (Philip Oxhorn et al. eds., 2004).

121 See generally Davidson, supra note 110. See also van Klinken, supra note112.

122 See e.g., supra note 33.

123 Rawski \& MacDougall, supra note 117, at 154 (citing I'Ketut Widia).

124 Pepih Nugraha, Pemerintah Tak Berhak Menghadang [The Government has No Right to Obstruct], KomPAS (JAKARTA), Nov. 11, 2006, available at http://kompas.com/kompas-cetak (last visited on Dec. 7, 2007).

125 Jakarta Provincial Government Regional Regulation No. 4 of 2004 concerning Population. The Regulation requires, among other things, a "letter of guarantee" from the "migrant's" employer. 
permanently. 126 In addition to violations of the right to internal freedom movement, some regional governments have recently proposed "protecting" Indonesian women who are considering engaging in migrant work abroad by simply prohibiting them from doing this.127 Such a policy would be a clear violation of the right to leave one's country. 128

\section{Freedom of Religion}

Otda has spawned a range of Regional Regulations concerning "public order" which have been inspired by conservative interpretations of Islam. 129 These Regulations have, in turn, either required or inspired actions that have violated the right to "freedom of thought, conscience and religion." 130 These actions fall into three general categories. Firstly, some regional governments have stipulated or issued punishments against Muslims who do not conform to conservative Islamic values. This has included, for example, the prohibition of the Ahmadiyah Islamic sect in West Lombok District,131 the whipping of Muslim men in Aceh for missing Friday Prayers three times in a row without a valid excuse 132 and the jailing of a school principal and social worker in Malang District for conducting Islamic prayers in two languages. 133 Secondly, Regional Governments have ordered the closure of places of worship for non-Muslims (and nonconformist Muslims), ${ }^{134}$ hindered efforts to obtain the required permission to build such

126 Medelina K. Hendytio, Regional Autonomy: Its Social and Cultural Impact, in Regional Autonomy and SocioEconomic Development in Indonesia (T.A. Legowo \& Muneo Takahashi, eds., 2003).

127 Luke L. Arnold, Indonesian Laws, Policies and Practices concerning Indonesian Migrant Workers: A Situational REview AND Set of ReCOMmEndations (forthcoming 2009).

128 UDHR, supra note 75, at art. 13(2); ICCPR, supra note 74, at art. 12(2).

129 Although many of these Regional Regulations are clearly inspired by conservative Islam, and make reference to Islamic values in their preambles, regional leaders justify them on the grounds of "public order" given that religious affairs remains the exclusive jurisdiction of the Central Government (except in Aceh). Satriyo, supra note 5, at 221.

130 UDHR, supra note 75, at art. 18 (the right is also expressed in ICCPR, supra note 74, at arts. 2, 18, 20, 26 and 27; and ICESCR , supra note 74, at art. 2). This phenomenon also appears to have inspired a backlash by majority Christian areas, with Manokwari Municipality recently proposing to pass a Regional Regulation which would mandate placing crucifixes in public offices and prohibit working on Sunday. Mengatur Daerah Berbasis Agama [Regulating Regions based on Religion], Tempo Interaktif (Jakarta), May 14, 2007, available at http://www.tempointeraktif.com (last visited on Feb. 12 2008).

131 Ahmadiyah Lombok Mengadu ke Komnas HAM [Lombok's Ahmadiyah Community Files Complaint with the National Human Rights Commission], Tempo Interaktif (Jakarta), Feb. 10, 2006, available at http://www.tempointeraktif.com (last visited on Dec. 3, 2007).

132 Ninuk Mardiana Pambudy, Membangun Otonomi Daerah bagi Semua [Building Regional Autonomy for All], KoMPAS (JAKARTA), Oct. 16, 2006, available at http://www.kompas.com/kompas-cetak (last visited on Dec. 3, 2007).

133 The Otda laws were specifically cited as giving the authority to do this. Victims of MUI's Discriminatory Fatwa Reports to Gus Dur, DPR and Human Rights Commission, GusDur.Net (JAKARTA), June 2005, available at http://www.gusdur.net (last visited on Feb. 11, 2008).

134 See e.g., Berita Perhimpunan Bantuan Hukum dan Hak Asasi Manusia Indonesia [Press Release of the Indonesian Association for Legal Aid and Human Rights], Camat Tambora menutup Gereja Kristus Damai [Tambora Sub-district 
houses of worship135 and turned a blind eye to their destruction by vigilante groups. Thirdly, some Regional Regulations have required non-Muslims to follow Islamic teachings, such as a Regional Regulation in Lima Puluh Kota District that all students and public servants in the district wear Islamic clothing. 136

\section{Otda and Mixed Results for International Human Rights}

\section{Gender Equality}

Otda is leading to significant ramifications for the human right to gender equality 137 throughout Indonesia, though it is not possible to categorise the overall impact as either positive or negative: for Indonesian women, "decentralization has two faces." 138 On one hand, a number of gender discriminatory Regional Regulations have emerged - the National Commission on Violence against Women last estimated the total to be 29139 as traditional value systems have been revived.140 These include the clothing rules mentioned above, 141 which have led to vigilante actions such as the shaving of women's hair for not wearing a headscarf.142 A further example of discriminatory Regional Regulations can be found in those ostensibly aimed at prohibiting "prostitution", which have at times been used to enforce a de facto curfew against women leaving their homes at night.143 Another factor working against the realisation of gender equality under Otda is that, statistically, the more localised the level of parliament, the lower the portion of women representatives. 144 Many regional governments have taken steps which may

Head shuts down Peace of Christ Church], Nov. 30, 2007, available at http://www.pbhi.or.id (last visited on Dec. 3, 2007).

135 Melissa Crouch, Regulating Places of Worship in Indonesia: Upholding Freedom of Religion for Religious Minorities?, 1 Sing. J. LeG. STUd. 96, 104 (2007).

136 Lima Puluh Kota District Regional Regulation No. 5 of 2003 concerning the Obligation to Wear Muslim Clothing.

137 UDHR, supra note 75, at art. 2; ICCPR, supra note 74, at arts. 2, 3 and 26; ICESCR, supra note 74, at arts. 2 and 3.

138 Edriana Noerdin et al., Decentralization as a Narrative of Opportunity for Women IN Indonesia 13 (2007).

139 Ninuk Mardiana Pambudy, Hak Asasi Perempuan: Membangun Masyarakat yang Tidak Diskriminatif [Women's Fundamental Rights: Building a Non-discriminative Society], KomPAS (JAKARTA), Dec. 28, 2006, available at http://www.kompas.com/kompas-cetak (last visited on Dec. 3, 2007).

140 Satriyo, supra note 5 , at 222 .

141 Though the laws themselves potentially do not constitute a violation of women's rights under the International Bill of Rights, they have been found to have been "disproportionately enforced against women." United Nations Committee on the Elimination of Discrimination against Women, Thirty-ninth session: Concluding comments of the Committee on the Elimination of Discrimination against Women - Indonesia, II 12, Doc CEDAW/C/IDN/CO/5, 10 (Aug. 2007).

142 Indonesian Women's Research Institute, Potret Perempuan Dalam Era Otonomi Daerah [A Portrait of Women in THE ERA of Regional Autonomy] (2007).

143 The most notable example is Tangerang Municipality Regional Regulation No. 8 of 2005 concerning Prostitution, which has led to the arrests of women on their way home from night shifts. Pambudy, supra note 139.

144 Women make up approximately eleven percent of the National Parliament, ten percent of all provincial parliamentarians and eight percent of all district/municipal parliamentarians. Noerdin et al., supra note 138, at 19-22. 
prevent women's participation in public life from improving, such as downgrading gender awareness campaigns 145 and failing to keep gender-disaggregated statistics.146

Otda has also supported gender equality in a number of ways. Some concrete legislative gains have been made through Regional Regulations, such as a Regional Regulation in North Sulawesi Province that provides for the dismissal of regional public servants who fail to take appropriate action against the trafficking of women ${ }^{147}$ and another in Mataram Municipality which encourages women to participate in the development of public policy. 148 Space has also opened up for women's organisations to mobilise around campaigns for local-level legislative protection for women, such as legislation to support national laws on domestic violence.149 In addition, a range of creative initiatives to support the gender equality have arisen throughout the archipelago, many of which have the potential to be used by women's organisations in other parts of the country to lobby for change. Such initiatives include, for example, the establishment of a regional government-funded women's crisis centre; 150 a free mobile pap smear testing unit;151 a regional government-funded radio programme on gender issues; 152 training sessions for regional governments on gender-based budget drafting; 153 the development of a Provincial Women's Development Index;154 and the promotion of gender-progressive interpretations of Islam. 155

\section{Access to Education and Health}

Although information relating to Otda's impact on social and economic human rights is almost non-existent, preliminary evidence indicates it is resulting in very mixed

145 Sukabumi Municipality, for example, has relegated gender awareness raising to the Municipality's Family Planning Unit, which has little or no influence over legislative or other executive organs. See e.g., Sukabumi Municipality Regional Regulation No. 14 of 2000 concerning Government Authority, cited in Indonesian Women's Research Institute, supra note 142.

146 Eko Bambang S, Otonomi Daerah Masih Mengesampingkan Peran Perempuan [Regional Autonomy Still Sidelines the Role of Women], JuRnal Perempuan (JAKARTA), Jan. 12, 2004, available at http://www.jurnalperempuan.com (last visited on Dec. 3, 2007); see also Satriyo, supra note 5, at 221.

147 North Sulawesi Province Regional Regulation No. 1 of 2004 concerning the Prevention and Elimination of Human Trafficking particularly of Women and Children.

148 Mataram Municipality Regional Regulation No. 27 of 2001 on Community Stakeholder-based Development Consultations, cited in Noerdin et al., supra note 138, at 18.

149 Dian Yuliastuti, Aktifis Desak Perda Anti Kekerasan Terhadap Perempuan [Activists Push for a Regional Regulation on Violence against Women], TEMPO INTERAKTIF (JAKARTA), Nov. 28, 2004, available at http://www.tempointeraktif. com (last visited on Feb. 14, 2008).

150 In Sidoarjo District, East Java Province. Satriyo, supra note 5, at 224.

151 In Gianyar District, Bali Province. Id.

152 In South Kalimantan Province. Id.

153 In Yogyakarta Province. Id.

154 In South Sumatra Province. Id. at 223.

155 In various parts of the country. Id. at 227. 
outcomes. It is clear, for example, that Otda is creating massive regional wealth disparities. The Gross Regional Domestic Product (GRDP) per capita of the richest province, East Kalimantan, is twelve times higher than that that of the poorest province, East Nusa Tenggara.156 Even after the DAU and DAK equalisation mechanisms have been applied,157 this leads to significant differences in government revenues and therefore capacity to invest in providing services such as education and health. 158 Several wealthy areas have used their revenue to abolish primary school fees and provide free or subsidised health care, while access to these services in many poorer regions appears to have decreased.159

Regional economic disparities are not the only factor affecting the "right of everyone to the enjoyment of the highest attainable standard of physical and mental health" 160 and the "right of everyone to education." 161 Political will is also a factor, as evidence by the remarkable efforts of the Jembrana District, with only half the GRDP per capita of the average East Kalimantan district/municipality, 162 has introduced free basic education and health care for its citizens. One of the poorest regions in Indonesia, Kupang Municipality, has now indicated that it wishes to implement a similar scheme.163 Otda has also improved the realisation of rights to education and health by facilitating policies which respond to local needs. 164 Again in Jembrana District, the District Government identified the price of obtaining the necessary identification

156 IDR 9.2 million compared with IDR 756,000:.Armida S. Alisjahbana, SMERU Research Institute, Regional Inequality in Indonesia, Oct. 2005, 29.

157 See supra Part III.

158 The Economist estimates that the districts and municipalities in East Kalimantan receive revenues 32 times more, on average, than those in East Nusa Tenggara. Thousand-Island Dressing, THE EconomisT, 12 November 2004.

159 See e.g., Stein Kristiansen \& Purwo Santoso, Decentralizing Education in Indonesia, 26 INT’L. J. ED. DEv. 513 (2006); Stein Kristiansen \& Purwo Santoso, Surviving Decentralization? Impacts of Regional Autonomy on Health Service Provision in Indonesia, 77 HeALth Policy 247 (2006); Benny K. Harman, HAM dan Otonomi Daerah [Human Rights and Regional Autonomy], SuARa Pembaruan (Jakarta), May 29, 2007, available at http://www.suarapembaruan.com (last visited on Feb. 9, 2008); Rita A. Widiadana, Prosperous Kutai Revives Past Glory, The JaKarTA Post (JAKARTA), Oct. 10, 2002, available at http://www.thejakartapost.com (last visited on Dec. 3, 2007); Thousand-Island Dressing, supra note 158; Satriyo, supra note 5, at 224; Pambudy, Membangun Otonomi Daerah Bagi Semua [Building Regional Autonomy for All], supra note 132.

160 ICESCR, supra note 74, at art. 12.

161 ICESCR, supra note 74, at art. 13.

162 Central Bureau of Statistics(BPS), Statistics of JembRana REGENCY 2001, available at http://www.bps.go.id/ bali/ 2001/regency/Jembrana/jbn-ecoe.htm (last visited on Feb. 19, 2008).

163 Sugeng Bahagijo, A Few Good People and Local Government, The JakarTA Post (JAKARTA), June 19, 2007, available at http://www.thejakartapost.com (last visited on Feb. 20, 2008).

164 See e.g., Hendytio, supra note 126. For a discussion on this notion in the context of the Philippines, See e.g., Leonora C. Angeles and Fransisco A. Magno, The Philippines: Decentralization, Local Government and Citizen Action, in Decentralization, Democratic Governance and Civil Society in Comparative Perspective: Africa, Asia AND Latin America 211, 247-48 (PhILIP OXHoRn et al. eds., 2004). 
documents as an obstacle to accessing education and health services, and responded by providing these documents free of charge. 165 Another positive example is Bantul District, where nutrition levels were raised by increasing egg consumption though the distribution of chickens to families. 166 However, the autonomy to make positive decisions at a local level has been accompanied with the freedom to do the opposite. Health outcomes are being compromised by a general shift at the local level away from long-term preventative health measures, 167 and access to education in some regions is being compromised in some regions by the selection and promotion of public servants on the basis of ethnic affiliation rather than merit. 168

\section{International Human Rights and Lessons for Otda}

The above examination of Otda from an International Human Rights perspective has revealed that it has led to very significant and highly varied outcomes for the human rights of Indonesians. Where Otda has contributed to human rights violations, there appear to be three inter-related factors at play. The first is the way in which "accumulated historical frustrations" from the hyper-centralisation period 169 have given rise to a relativist approach to human rights among many newly empowered local policy-makers. The West Java Provincial Government, for example, has recently stated that "global" human rights are a "source of moral and environmental destruction" and are not compatible with the "dominant cultural and religious values" of the region.170 Secondly, Otda has opened space for the emergence of new but historically rooted forms of xenophobia. 171 Thirdly, the financial burden of local governments has given rise to a common belief that priority must be given to increasing local revenues before human rights considerations can be considered. 172

Much can be done to address the Otda-facilitated violations of international human rights. National human rights institutions - and the international donors which finance many of them - could begin decentralizing their own activities. They could also support

165 Indonesian National Consultation of the United Nations Commission on Legal Empowerment of the Poor, Legal Empowerment of the Poor: Lessons Learned from Indonesia, July 2007, 9.

166 Kristiansen \& Santoso, Surviving Decentralization? Impacts of Regional Autonomy on Health Service Provision in Indonesia, supra note 159 , at 255 .

167 Id.

168 Interview with Leliana Setiono, British Council School Links Project Team Member, Feb. 9, 2008.

169 Resosudarmo, supra note 52, at 112.

170 Bappeda Jawa Barat [West Java Regional Development Agency], Rumusan FGD RPJPD Provinsi JAWA BARAT TAHUN 2005 - 2025 [Summaries of FGDs on the Draft Long-Term Regional Development Plan for West Java: 2005-2025] (2007).

171 Rawski \& MacDougall, supra note 117, at 144.

172 Hidayat \& Antlöv, supra note 26, at 280. 
the establishment of a much more robust system for reviewing Regional Regulations. Many Regional Regulations clearly contradict higher laws, 173 such as the Constitution 174 and the Human Rights Law,175 and the many examples of discriminatory "public order" legislation potentially conflict with the Central Government's exclusive jurisdiction over religious affairs under the Otda laws themselves. However, the right of the Central Government to annul such legislation has been ineffective due to the sheer number of Regional Regulations being promulgated 176 and what appears to be an implicit political compromise on the part of the Ministry of Home Affairs (the Ministry charged with undertaking the executive reviews) whereby ultra vires Regional Regulations which concern finance will be annulled but others will be simply ignored.177

In addition to specifying clearer rules for executive review, the realisation of international human rights may also require providing members of the pubic an opportunity to have Regional Regulations judicially reviewed.178 At present, a right to have Regional Regulations judicially reviewed for compliance with national laws such as the Human Rights Act technically exists179 but the Supreme Court has construed it very narrowly. Firstly, it has barred judicial review of Regional Regulations that are more than 180 days old; 180 secondly, it has recently declared that it will only examine

173 Armada Riyanto, Panorama Violasi HAM [A Panorama of Human Rights Violations], Kompas (JaKARTA), Dec. 10, 2004, available at http://www.kompas.com/kompas-cetak (last visited on Dec. 7, 2007).

174 The Constitution of the Republic of Indonesia 1945 guarantees the right to be free from discrimination (which it repreats with respect to children), the right to choose one's place of residence, freedom of religion, the right to education, the right to health care and the right to equal opportunity in government.

175 Law No. 39 of 1999 concerning Human Rights. This Law, for example, prohibits discrimination on racial or gender grounds, guarantees freedom of movement and freedom of religion and holds that all all children have a right to a "decent standard" of education and healthcare.

176 Between 2002 and 2007, in the area of finance alone an estimated 10,000 Regional Regulations were promulaged. The Central Government has annulled approximately 1,500 Regional Regulations in total, but has admitted to finding it difficult to monitor all of them. See e.g., Yance Arizona, Disparitas Pengujian Peraturan Daerah: Suatu Tinjauan Normatif [Disparities in Reviewing Regional Regulations: A Normative Appraisal], 8 January 2008, available at http://yancearizona.wordpress.com (last visited on Feb. 12, 2008); Rini Kustiani, Pemerintah Batalkan 1.406 Perda [Government Annuls 1,406 Regional Regulations], Tempo Interaktif (JAKARTA), Nov. 19, 2007, available at http://www.tempointeraktif.com (last visited on Feb. 12, 2008); Ary Hermawan, Sexual Minorities Protest Bylaws, The JAKARTA PoSt (JAKARTA), Oct. 3, 2006, available at http://www.thejakartapost.com (last visited on Feb. 11, 2008).

177 See e.g., Pambudy, supra note 139; see also Sebagian Besar Perda Tanpa Didahului Naskah Akademis [A large number of Regional Regulations are not Preceded by Academic Drafts], KoMPAS (JAKARTA), Oct. 14, 2006, available at http://www.kompas.com/kompas-cetak (last visited on Dec. 7, 2007).

178 A clear right to judicial review with respect to administrative action already exists pursuant to the jurisdiction of the Administrative Court. See e.g., Komisi Nasional Anti Kekerasan terhadap Perempuan [National Commission on Violence against Women], Panduan Pemantauan Kebijakan Daerah dengan Perspektif Ham \& Keadilan Gender [A Guide to Monitoring Regional Policies from a Human Rights and Gender Equality Perspective] (2007).

179 See supra Part III.

180 Supreme Court Regulation No. 1 of 2004 concerning Judicial Review of Legislation $\S 2(4)$. See also Arizona, supra note 176 (discussing the likely human rights issues raised by this rule). 
whether Regional Regulations have complied with formal legislative requirements, such as being properly passed by the Regional Parliament, and will not examine the substance of the legislation.181 The Otda legal framework must therefore be amended if it is to entail the right to a full judicial review.

The above examination of international human rights under Otda clearly calls into question the "romantic return to indigeneity" 182 that Otda in part envisages. The various examples of human rights violations linked to identity-based forms of belonging instead point to the need for Otda to foster "residency-based citizenship." 183 One way it can do this is to move away from a recent trend toward creating ethnically delineated regions. 184 Another way to promote residency-based citizenship, though it sounds counter-intuitive, is to constitutionally enshrine the rights of the regions. The present situation, where at any moment the Central Government could revoke the current arrangements, leads regional governments to perceive Otda as a "retractable privilege" 185 and therefore over-extend their authority186 - and over-exert their parochial identity in an attempt to put the situation beyond a point where it can be wound back. 187 The regions' insecurity about the Central Government taking back devolved power - an insecurity which is perhaps not entirely unwarranted 188 - may also explain their emphasis, as discussed above, on prioritising their revenue bases above human rights. 189

181 This declaration was made in relation to a judicial review of a Regional Regional which essentially allowed the Tangerang District Government to impose a de facto curfew against women, as discussed above in Part IV(C)(i). Oddly, the overall rejection of the applicants' case was announced in a press conference and no written decision has been made available to them. See e.g., Indonesian National Commission on Violence Against Women, Crucial Issues Related to the Implementation of the CEDAW Convention in Indonesia (July 18, 2007), available at http://www.iwraw-ap.org (last visited on Feb. 12, 2008); see also MA Tegaskan Perda Pelarangan Pelacuran Tidak Bertentangan dengan UU [Supreme Court Emphasises that Prostitution Ban Regional Regulation does not Conflict with Law], ANTARA News (JakARTA), Apr. 13, 2007, available at http://www.antara.co.id (last visited on Feb. 12, 2008).

182 Rawski \& MacDougall, supra note 117, at 153; see also Lungisile Ntsebeza, Democratic DeCENTRALIZATION AND Traditional Authority: Dilemmas of Land Administration in Rural South Africa, in Democratic Decentralization through a Natural Resource Lens 71 (Jesse C. Ribot \& AnNe M. Larson eds., 2005).

183 Jesse C. Ribot, Waiting for Democracy: The Politics of Choice in Natural Resource Decentralization 4 (2004).

184 While the current policy of creating new regions based mainly on ethnicity may ease tensions in the short-term, the example of Ethiopia demonstrates that it may simply reinforce ethnic identity and promote conflict in the long-term. See generally Alemante G. Selassie, Ethnic Federalism: Its Promise and Pitfalls for Africa, 28 Yale J. InT'L. L. 51, 54 (2003).

185 Ribot, supra note 183 , at 81 .

186 This is what Indonesians refer to as otonomi kebablasan or "overreacted autonomy."

187 See e.g., McCarthy, supra note 12, at 162.

188 Hidayat \& Antlöv describe, for example, how the Central Government often jusitifies examples of incremental clawbacks on the basis that the "regions are not ready yet," when in actual fact it is more likely that the Central Government is not ready. Hidayat \& Antlöv, supra note 26, at 279.

189 This may be compounded by the fact that insecure regional authority can also prevent the development of local-level 


\section{International Human Rights through an Otda lens}

A thorough examination of the relationship between Otda and international human rights requires not only an analysis of how the former is informed by the latter, but also of what Otda tells us about international human rights. Such an analysis is important because, although people will always struggle for their rights, "they will not build their struggle around the notion of human rights unless [its] language and those who wish to popularise it speak to their aspirations and survival." 190 This is a factor behind why human rights has been largely missing from the Otda discourse. This Part discusses three possible reasons why the language and proponents of international human rights are not speaking loudly to the "aspirations and survival" vis-á-vis Otda: its focus on the nation-state, its failure to address situations which "fall between" rights and its internal tensions. These reasons in turn highlight some important current limits and possibilities of international human rights.

\section{A. Otda and the Nation-State Focus of International Human Rights} international human rights is characterised by "deference to the legal forms upon which human rights is built," 191 including international law's focus on the nation-state as both the primary protector and violator of human rights. 192 This gives rise to several problems when international human rights is confronted with a situation like Otda. Firstly, international human rights's focus on the national level has led to its neglect of the relationship between "internal" (ie sub-national) structures of government and the protection of rights, 193 even in the zero-sum game of devolving power from the centre to the regions. 194 This partly explains why international human rights has offered little or no guidance on how a system such as Otda might be implemented. Secondly, due to the fact that it conceives the hyphen between nation and state as unproblematic, 195

civil society. Ribot, supra note 183 , at 54 .

190 Chidi Anselm Odinkalu, Carnegie Council on Ethics and International Affairs, Why More Africans Don't Use Human Rights Language (2005), available at http://www.cceia.org/resources/publications/dialogue/index.html (last visited on Feb. 23, 2008).

191 Kennedy, supra note 1, at 32.

192 Martti Koskenniemi, From Apology to Utopia: The Structure of International Legal Argument (1989).

193 Chen, supra note 7, at 872. This is despite the fact that in the twenty-first century, the governments with the most radical reform agendas are likely to be situated at sub-national level (e.g., the Livingstone Labour Government in London or the Left Democratic Front Government in Kerala).

194 Ralph R. Premdas, Self-Determination and Decentralization in the Caribbean: Tobago and Nevis, paper produced for the St Kitts and Nevis Country Conference, May 2000, available at http://www.uwichill.edu.bb/bnccde/sk\&n (last visited on Feb. 12, 2008).

195 Susan Marks, Guarding the Gates with Two Faces: International Law and Political Reconstruction, 6 GLOB. LEG. STUD. J. 467, 485 (1999). 
international human rights sends confusing signals when confronted with situations such as Otda, where devolved power has been used in ways that link sub-national polities with particular groups. 196 Thirdly, international human rights places itself in an antagonistic relationship with Otda by privileging the Central Government. While commentators have for over half a century pointed to how decentralized forms of government are "ill-adapted to international cooperation," 197 they have generally neglected to state the converse: notions like international human rights are ill-adapted to decentralized government. Even in relation to the rights to education and health, for example, Indonesia's Central Government remains ultimately responsible for upholding international human rights despite having devolved most of its authority in these areas. 198 Fourthly, in addition to backgrounding sub-national governments, international human rights backgrounds harms brought about by private groups. 199 This is of particular importance in situations such at Otda, where the withdrawal of Central Government control has led to a well-documented rise in organised private violence (albeit often condoned by regional governments).200 All four of these problems point to current limitations in the capacity of international human rights to speak to the survival and aspirations of people, but in doing so also signal possible future directions for international human rights.

\section{B. Otda and Situations which "Fall between" International Human Rights}

Another way in which Otda informs understandings of international human rights is by highlighting the ways in which Otda has created "situations which fall between rights." 201 One such situation is the clear disparities in wealth and power being created by Otda.202 International human rights has little to say about either the increasing inequality between regions, or the ways in which regional elites are using Otda to

\footnotetext{
196 See discussion infra Part V.C.

197 Max Sorensen, Federal States and the International Protection of Human Rights, 46 AM. J. INT'L. L. 195, 218 (1952).

198 This has in turn allowed international organizations (human rights technical assistance bodies included) to simply pick and choose which regional governments they work with, a luxury International Human Rights does not afford at a nation-state level.

199 Kennedy, supra note 1, at 10-11.

200 See e.g., Timothy Lindsey, The Criminal State: Premanisme and the New Indonesia, in Autonomy AND Disintegration in Indonesia (Damien Kingsbury \& Harry Aveling eds., 2003); Vedi Hadiz, Reorganizing Political Power in Indonesia: A Reconsideration of So-called "Democratic Traditions," in Regionalism In Post-Suharto Indonesia (MARIBETh ERB et al. eds., 2005); Davidson, supra note110; Stein Kristiansen \& Lambang Trijono, Authority and Law Enforcement: Local Government Reforms and Security Systems in Indonesia, 27 CONTEMPORARY Southeast AsIa 236 (2005); Luke L. Arnold, Labour Law and Practice in Post-Suharto Indonesia, in IndonESIA: LAW AND Society 532 (Tiмотнy LINDSEY ed., 2008).

201 Kennedy, supra note 1, at 22.

202 See supra Part IV.C.ii.
} 
legitimate inequality within regions. ${ }^{203}$ Another situation which falls between rights is the rise of various "subtle forms of cultural and political violence." 204 This includes, for example, the strengthening under Otda of myths which promote ethnocentricism and the use of vigilantism. International human rights does not concern itself with these forms of violence, even though it is through such myths that direct or structural violence is legitimised.205 In this way, Otda demonstrates how international human rights can be blind to the fact that human beings are often driven equally as much by stories and emotions as they are persuaded by rational arguments. ${ }^{206}$

Otda also demonstrates how the hopes and aspirations of many people with respect to good governance frequently fall between rights. Although international human rights recognises a right to participate in government, 207 it does not explicitly recognise the importance to people of transparent, accountable and effective governments. ${ }^{208}$ As such, despite the fact that rampant regional government corruption and rent-seeking under Otda are having significant impacts on people's dignity, freedom and sense of justice,209 Indonesians have generally not used international human rights language to respond to this situation. It need not be this way. The South African Bill of Rights, 210 for example, contains rights to access information, 211 receive just administrative action, 212 and access courts of law.213 In Indonesia, the difficulties associated with reviewing Regional Regulations, 214 in addition to the pervasive corruption and rent-seeking under Otda, show how international human rights may hold more relevance for people if it adopted similar measures.

203 See e.g., Patrick Barron \& Samuel Clark, World Bank, Decentralizing Inequality? Center-Periphery Relations, Local Governance, AND Conflict in ACEH (2006).

204 Rawski \& MacDougall, supra note 117, 143.

205 Johan Galtung, Cultural Violence, 27 J. Peace Research 291 (1990). See also Bernadette Muthien \& Helene Combrinck, When Rights are Wronged: Gender-Based Violence and Human Rights in Africa, in transnational Transgressions: African Women, Struggle, and Social Transformation in Global Perspective (M. Bahati Kuumba \& Monica WHITE eds., 2004).

206 See e.g., Randall Peerenboom, Human Rights, China and Cross-Cultural Inquiry: Philosophy, History and Power Politics, 55 Philosophy East \& West 283 (2005).

207 See supra Part IV.

208 For a summary of the importance of this to people in the developing world, see generally Navin Girishankar et al., Governance, in A SOURCEBOoK For Poverty Reduction Strategies (World BANK ed., 2002).

209 See generally Hidayat, supra note 27.

210 Constitution of the Republic of South Africa Act 108 of 1996, S.AFr. Const. 1996. ch. 2.

211 Id. $\S 32$.

212 Id. $\S 33$.

213 Id. $\S 34$.

214 See supra Part IV.D. 


\section{Otda and Tensions within International Human Rights}

The fact that a causal relationship exists between Otda and both the realisation and violation of international human rights points to internal tensions within international human rights. The enhanced realisation of rights to self-determination and participation in government, 215 for example, has led to an "institutionalised separateness" 216 under which proponents of sectarianism have gained traction. This has not only directly facilitated the violation of other international human rights such as freedom of movement and freedom of religion; it has also thwarted attempts of people to mobilise around common goals (such as environmental degradation or economic exploitation) other than the interests of a particular ethnic or religious group. ${ }^{217}$ Given the importance of bottom-up political pressure for the realisation of human rights, 218 even in states such as Indonesia which nominally recognise most international human rights, such a situation could be accused of leading to "more a museum of social and cultural antiquities than a human rights ideal." 219 International human rights could therefore be accused of containing internal inconsistencies. This is compounded by the fact that international human rights remains inept at providing guidance or setting priorities in situations when rights appear to be in conflict with each other. No attempts have been made, for example, to examine the ways in which decentralization may be sequenced in order to promote both the realisation of human rights and the full recognition of a universal (rather than parochial) human identity required to sustain this. 220 This is because many proponents of international human rights appear to support the view that all human rights are automatically mutually reinforcing, 221 regardless of factors such as the distribution of government power within a state. The strongly varied human rights situation under Otda, however, points to the notion that this is not necessarily the case. While certainly not disproving the notion that international human rights can be mutually reinforceable, the Otda experience tells us that international human rights needs to concern itself with what structures and safeguards within states can make this possible.

\footnotetext{
215 See supra Part IV.A.

216 InTERNATIONAL Human Rights IN CONTEXT, supra note 82, at 1294.

217 Maria Hartiningsih, Menyempitnya Ruang Kebersamaan [The Narrowing of Collective Space], KompAS (JAKARTA), Mar. 4, 2006, available at http://www.kompas.com/kompas-cetak (last visited on Dec. 7, 2007).

218 See e.g., Zackie Achmat, Law, Politics and Social Transformation, 32 InT'L. J. LEG. INF. 237 (2004).

219 International Human Rights IN ConTeXT, supra note 82, at 1294.

220 This is despite the fact that such a recognition is part of the spirit, if not the letter, of International Human Rights. Id. at 1294-1296.

221 William Twining, Law and the Millennium Development Goals: Like Water in Marriage?, UCL Lunch Hour Lecture Series, Dec. 4, 2007 (discussing the attitudes of several international human rights organizations toward Uganda's National Plan of Action to realise the Millenium Development Goals).
} 


\section{Conclusion}

In September 2007, the Indonesian Legal Aid and Human Rights Association (PBHI) released a statement entitled "The Human Rights Situation is Deteriorating: Regional Autonomy is Out of Control." 222 The statement marks a growing realisation in Indonesia of the relationship between international human rights and Otda. As this essay has shown, Otda has had a profound impact on international human rights in Indonesia. This impact has been significantly influenced by the historical, political and economic context in which Otda has been implemented - particularly the hypercentralisation of the New Order period, the Asian Economic Crisis which brought it to an end and the Reformasi movement which followed it. The impact itself has been complex and varied. Some rights, such as the right to (internal) self-determination and the right to participation in government, are now more widely realised due to Otda. The realisation of other rights, such as the rights to racial equality, freedom of movement and freedom of religion appears to have suffered under Otda. A third set of rights, which include the rights to gender equality, education and health, have been significantly influenced by Otda but not in ways that can be categorically described as either a step forward or a step back.

Interestingly, despite its demonstrated impact on human rights and the fact that it is being implemented in varying degrees across the developing world, decentralization can claim virtually no place in the "theatre of roles" 223 established by human rights vocabulary. Perhaps due to both the challenges it reveals within international human rights and its "lack of appeal and romanticism" relative to secessionist selfgovernment, 224 advocates of international human rights have largely ignored it particularly in a developing world context. As the Universal Declaration of Human Rights approaches its sixtieth anniversary, the capacity of human rights discourse to speak to the aspirations of people across the world requires that it engage with phenomena such as decentralization. As the lessons from Otda reveal,225 this may require significant changes in international human rights itself. It may need to shift its focus to actors other than simply nation-states, address key situations which "fall

\footnotetext{
222 Syamsuddin Radjab \& Suryadi Radjab, Perhimpunan Bantuan Hukum dan Hak Asasi Manusia Indonesia [Indonesian Assocation for Legal Aid and Human Rights], Siaran Pers No. 01/SP-PBHI/IX/2007: Memburuknya Kondisi Hak-hak Manusia: Otonomi Daerah Tidak Terkendali [Press Release No. 01/SP-PBHI/IX/2007: The Human Rights Situation is Deteriorating: Regional Autonomy is Out of Control], 10 September 2007. The statement called on the Central Government to evaluate the regional autonomy regime from a human rights perspective and on subnational governments to develop and implement action plans on human rights.

223 Kennedy, supra note 1, 14.

224 Welhengama, supra note 87, 437.

225 See supra Part V.
} 
between" currently recognised rights and deal more effectively with its internal tensions. This is will be no easy task, but may be necessary if international human rights is to continue to form part of the "foundation of freedom, justice and peace in the world." 226

226 Preamble to the UDHR, supra note 75. 